\title{
Achievement Anxiety of Prospective Teachers: A Research in the Context of Their Attitudes towards Public Staff Selection Examination ${ }^{\mathrm{i}}$
}

\author{
Durmuş Ümmet \\ Faculty of Atatürk Education, Marmara University, Turkey
}

Copyright $(2016$ by authors, all rights reserved. Authors agree that this article remains permanently open access under the terms of the Creative Commons Attribution License 4.0 International License

\begin{abstract}
The aim of this study is to examine the achievement anxiety of prospective teachers according to their attitudes to Public Staff Selection Examination (KPSS) and some demographic variables. The study group consists of 312 graduated and final year prospective teachers studying at different faculties of education and science and literature in Turkey. The data was collected by using Achievement Anxiety Scale, Public Staff Selection Examination Attitude Scale and personal information form that was prepared by the researcher. Relational screening method was used in the research. Analyzing the obtained findings, it was determined that there were significant relationships between facilitating achievement anxiety scores and debilitating achievement anxiety scores with KPSS attitude scale sub-dimensions. Besides, it was found that there were significant differences between their status of attending the KPSS course, daily study hours and the number of taking exams; whereas, it did not differ from the gender and department variables of prospective teachers' achievement anxiety. The findings were discussed within the scope of related literature and similar studies, then various proposals were brought forward.
\end{abstract}

Keywords Achievement Anxiety, Public Staff Examination, Attitude

\section{Introduction}

From the moment human being are born, we start to learn and perform what we learn [1]. At first, this performance is evaluated informally by parents, then with school age, it is started to be evaluated formally and it continues to be evaluated lifelong by other people. Each of these evaluations reveals anxiety emotion from any individual. Actually it can be said that anxiety emotion can be experienced from the early years of life and continues for lifetime. The concept of anxiety was started to be examined by the representative of psychoanalysis, Freud in 19th century. According to him, anxiety starts from the moment when we are born and continues for lifetime [2]. There are many definitions of anxiety in the literature, the common decision of the definition is "an unpleasant feeling or emotion" and it is highlighted that it is a feeling that is more or less experienced by almost everyone in their lives.

On their research about anxiety, Oner and Le Compte [3] defined anxiety as a state of mood to be perceived as threating or dangerous by individuals, its outcomes are unpleasant and up to the environmental stimulants. Although the conditions that cause to create anxiety differ from one individual or culture to the other, being without support, waiting the negative results, inner turmoil and uncertainty are the common factors that cause anxiety for all the cultures. If a person feels himself/herself safe and peaceful in an environment, he/she does not experience the anxiety or fear; whereas, another person may find that environment dangerous and thus, he/she can experience the fear or doubt [4]. One of the anxiety states can be described with uncertainty and danger feelings that are experienced immensely by some individuals is related to tests situations and it is explained in literature with the concept of test anxiety.

Test anxiety is an immense anxiety that starts before tests and occurs with various physical and psychological changes and affects an individual's performance during the test or exams [5].

Researching on test anxiety, Spielberger tried to explain the anxiety disorder related to tests and exams with the terms "state" and "trait" [6]. Spielberger \& Vagg [7] examined test anxiety in two dimensions: apprehensiveness and perceptiveness. "Apprehensiveness" dimension of test anxiety is a process that leads the individual to be distracted by having negative ideas as "what happens if I do not answer the questions, what happens if I fail" before and during the exam. "Perceptiveness" dimension of test anxiety is related to physiological part of text anxiety and it is a state of emerging after the stimulation of nervous system. It is the 
process that includes physiological reactions such as heart-throb, sweating, nervousness, dizziness and nausea.

Indeed, anxiety is necessary to cope with some situations; however, it will be a problem exceeding the normal level. When perceiving a threat, a person can feel himself/herself alarmed. Some mechanisms in our body start to work along with anxiety [8]. Named as facilitating anxiety, this positive anxiety is related to the perception of individual as it increases the performance. As the perception increases the performance, it is thought that it causes the individual makes more effort. Actually it can be considered as an impetus to set to work. Wittmajer [9] stated that people with low test anxiety levels have more effective study habits and they avoid postponing their academic tasks.

The other dimension of anxiety is debilitating anxiety that has negative effects on individuals. The experienced anxiety affects the individual's performance and behaviors [10]. People who immensely experience test anxiety may feel that their self-beings are in danger when taking an exam or to be evaluated. It may not only be related to exams, but also these people can experience fear, nervousness, excitement and stress when they speak or read a text in front of or among the other people. It is seen that people who immensely experience test anxiety do not show their cognitive skills sufficiently $[11,12]$. Similarly, it is known that the more achievement anxiety increases, the more negative psychological symptoms increase [13].

According to an announcement launched on the website of Ministry of National Education, a 22 years-old young person has taken approximately 1138 exams/tests during 16 years of education as including elementary school (8 lessons on average, for each lesson 6 exams in a year), secondary school (13 lessons on average, for each lesson 3 exams), high school (16 lessons on average, for each lesson 6 exams in a year), university (16 lessons on average, for each lesson 6 exams in a year) [14]. Therefore, it is obvious that achievement anxiety should be examined seriously in our country. Examining the reasons creating the anxiety by the experts and conducting studies to eliminate these reasons will be the best way to decrease the negative anxiety. In this context, examining the reasons of achievement anxiety, the reasons can be listed as the importance of the exam according to the person, the assigned roles to the person by his/her friends, family, teachers or society, inefficient studying methods, poor time management skills etc. [15, 16,17). Another concept that can be considered as important for creating anxiety towards tests/exams desired to be successful is the attitude to the tests/exams developed by the person.

Attitudes, described as some behaviors that cannot be observed by themselves but as tendencies that may lead to some observable behaviors, and whose roots are based on childhood may lead to positive or negative behaviors [18, 19]. Attitudes have three elements: Feelings, thoughts and behaviors. An attitude affects a person's feelings, thoughts and behaviors by harmonizing them all together. Cognitive, affective and behavioral components are closely associated with each other and these three elements are fully comprehended in established, strong attitudes [19, 20].

Attitudes that have important effects on our behaviors are expected to affect situations on which an individual is supposed to be successful like tests/exams and accordingly his/her behaviors, feelings and thoughts.

The aim of this research is to examine the achievement anxiety of prospective teachers according to their attitudes to Public Staff Selection Examination (KPSS) and some variables (gender, department of graduation, taking KPSS exam before, the status of attending to KPSS courses and daily study hours).

\section{Materials and Methods}

\subsection{Participants}

The study group consists of 312 graduated and final year prospective teachers studying at different faculties of education and science and literature in Turkey. 157 of prospective teachers are female and 155 of them are male. All the prospective teachers who formed the study group were selected by simple randomization method and voluntarily.

\subsection{Measures}

To determine demographic information of prospective teachers, 5 likert-type (gender, department of graduation, taking KPSS exam before, the status of attending to KPSS courses and daily study hours) personal information form that was prepared by the researcher was used. The measurement tools mentioned below were used for data collection.

\subsubsection{Achievement Anxiety Scale}

Developed by Alber and Haber (1960) and adapted by Kapıkıran [13] to measure anxiety related to academic situations, Achievement Anxiety Scale was used to measure the achievement anxiety of prospective teachers in the research. The scale had two sub-scales as Facilitating Achievement Anxiety (Başarı Kaygısı Ölçeği - Kolaylaştıcı - BKÖ-K) and Debilitating Achievement Anxiety (Başarı Kaygısı Ölçeği - Engelleyici - BKÖ-E). Facilitating Achievement Anxiety had 9 items and Debilitating Achievement Anxiety had 10 items. The scale has 5 likert-type 19 questions. Some items of the scale required reverse scoring. Some items had 1 score for "Never" category, the items required reverse scoring had 5 scores for the same category. In other words, some items had 5 scores for "Always" category, the items required reverse scoring had 1 score.

\subsubsection{Attitudes towards Public Staff Selection Examination} (KPSS) Scale

Developed by Ümmet and Otrar [21] to present the 
attitudes of prospective teachers towards KPSS, the scale had 45 items before reliability and validity tests were applied. The answer form was formed with five grading system. The developed scale was applied to 197 prospective teachers graduated from different universities' faculties of education in Istanbul and would take the KPSS in 2013. After applying statistical processes to determine reliability and validity, the actual form of the scale had 9 negative and 14 positive in total 23 expressions. As a result of explanatory factor analysis it was seen that the scale has 6 sub-scales (avoidance, academic contribution, the idea of justice, emotional stress, the inconsistency of the exam content, convergence). Cronbach Alpha reliability co-efficient of the scale was found as .85 .

\section{Findings}

The findings conducted with the statistical analysis in the scope of the aim of research were shown in table 1 .

An examination of Table 1 shows that there were positive significant relationships between prospective teachers' debilitating anxiety scores and KPSS attitude avoidance sub-dimension score at the level of $r=, 639 \mathrm{p}<, 05$; between the inconsistency of exam content sub-dimension scores at the level of $\mathrm{r}=, 131 \mathrm{p}<, 05$; whereas, there were negative significant relationships between prospective teachers' debilitating anxiety scores and KPSS attitude academic contribution sub-dimension score at the level of $\mathrm{r}=-, 556$ $\mathrm{p}<, 05$; between the idea of justice sub-dimension scores at the level of $r=-, 456 \mathrm{p}<, 05$ and between convergence sub-dimension score at the level of $\mathrm{r}=-, 581 \mathrm{p}<, 05$. There was no significant relationship between debilitating anxiety score and emotional stress sub-dimension scores.

There were negative significant relationships between prospective teachers' facilitating anxiety scores and KPSS attitude avoidance sub-dimension score at the level of $r=-, 485 p<, 05$; between emotional stress sub-dimension scores at the level of $r=-, 684 \mathrm{p}<, 05$ and between the inconsistency of exam content sub-dimension scores at the level of $\mathrm{r}=-, 216 \mathrm{p}<, 05$; whereas, there were positive significant relationships between prospective teachers' facilitating anxiety scores and KPSS attitude academic contribution sub- dimension score at the level of $r=, 428$ $\mathrm{p}<, 05$ and between the idea of justice sub-dimension scores at the level of $r=, 619 p<, 05$. There was no significant relationship between facilitating anxiety score and convergence sub-dimension scores.

Table 2 shows the analysis results of whether or not the participants' debilitating and facilitating anxieties differ from gender variable. Both debilitating and facilitating achievement anxiety of the participants did not significantly differ from gender variables $(\mathrm{p}>0.50)$.

Table 1. Pearson correlations for between debilitating anxiety-facilitating anxiety and KPSS attitudes' sub-dimensions

\begin{tabular}{|c|c|c|c|c|c|c|c|}
\hline Achievement Anxiety & & Avoiding & $\begin{array}{c}\text { Academic } \\
\text { Contribution }\end{array}$ & $\begin{array}{c}\text { The Idea of } \\
\text { Justice }\end{array}$ & $\begin{array}{c}\text { Emotional } \\
\text { Stress }\end{array}$ & $\begin{array}{c}\text { Inconsistency of } \\
\text { Exam Content }\end{array}$ & Convergence \\
\hline \multirow{3}{*}{ Debilitating Anxiety } & $\mathrm{r}$ & $639^{* *}$ &,$- 556^{* *}$ &,$- 456^{* *}$ &, 032 &, $131^{*}$ &,$- 581^{* *}$ \\
\hline & $\mathrm{p}$ &, 000 &, 000 &, 000 &, 576 &, 021 &, 000 \\
\hline & $\mathrm{N}$ & 312 & 312 & 312 & 312 & 312 & 312 \\
\hline \multirow{3}{*}{ Facilitating Anxiety } & $\mathrm{r}$ &,$- 485^{* *}$ &, $428^{* *}$ &, $619^{* *}$ &,$- 684^{* *}$ &,$- 216^{* *}$ &,- 003 \\
\hline & $\mathrm{p}$ &, 000 &, 000 &, 000 &, 000 &, 000 &, 954 \\
\hline & $\mathrm{N}$ & 312 & 312 & 312 & 312 & 312 & 312 \\
\hline
\end{tabular}

$* * * \mathrm{p}<.001 ; \quad * * \mathrm{p}<.010 ; \quad * \mathrm{p}<.050$

Table 2. İndependent sample $t$ test for gender and achievement anxiety

\begin{tabular}{|c|c|c|c|c|c|c|c|}
\hline \multirow{2}{*}{ Achievement Anxiety } & \multirow{2}{*}{ Gender } & \multirow{2}{*}{$\mathrm{n}$} & \multirow{2}{*}{ Mean } & \multirow{2}{*}{ s.d. } & \multicolumn{3}{|c|}{$t$ Test } \\
\hline & & & & & $\mathrm{df}$ & $\mathrm{t}$ & $\mathrm{P}$ \\
\hline \multirow{2}{*}{ Debilitating Anxiety } & Female & 157 & 28,84 & 5,09 & \multirow{2}{*}{310} & \multirow{2}{*}{,- 888} & \multirow{2}{*}{, 177} \\
\hline & Male & 155 & 29,33 & 4,60 & & & \\
\hline \multirow{2}{*}{ Facilitating Anxiety } & Female & 157 & 29,50 & 4,40 & \multirow{2}{*}{310} & \multirow{2}{*}{$-1,480$} & \multirow{2}{*}{, 414} \\
\hline & Male & 155 & 30,30 & 5,04 & & & \\
\hline
\end{tabular}

Table 3. İndependent sample $t$ test for status of attending KPSS courses and achievement anxiety

\begin{tabular}{|c|c|c|c|c|c|c|c|}
\hline \multirow{2}{*}{ Achievement Anxiety } & \multirow{2}{*}{$\begin{array}{l}\text { Status of Attending } \\
\text { KPSS Courses }\end{array}$} & \multirow{2}{*}{$\mathrm{n}$} & \multirow{2}{*}{ Mean } & \multirow{2}{*}{ s.d. } & \multicolumn{3}{|c|}{$\begin{array}{ll}t & \text { Test } \\
\end{array}$} \\
\hline & & & & & $\mathrm{df}$ & $\mathrm{t}$ & $\mathrm{P}$ \\
\hline \multirow{2}{*}{ Debilitating Anxiety } & Yes & 189 & 29,84 & 4,13 & \multirow{2}{*}{310} & \multirow{2}{*}{4,078} & \multirow{2}{*}{, $002 * *$} \\
\hline & No & 75 & 27,34 & 5,29 & & & \\
\hline \multirow{2}{*}{ Facilitating Anxiety } & Yes & 189 & 30,43 & 4,85 & \multirow{2}{*}{310} & \multirow{2}{*}{3,065} & \multirow{2}{*}{,013** } \\
\hline & No & 75 & 28,52 & 3,81 & & & \\
\hline
\end{tabular}

$* * * \mathrm{p}<.001 ; \quad * * \mathrm{p}<.010 ; \quad * \mathrm{p}<.050$ 
Table 3 shows the analysis results of whether or not the participants' debilitating and facilitating anxieties differ from their status of attending KPSS courses. Examining the related table, statistically both debilitating and facilitating achievement anxiety scores of prospective teachers who attend KPSS courses were significantly higher than those who do not attend KPSS courses $(\mathrm{p}<0.50)$. In other words, prospective teachers who attend KPSS courses experience both debilitating and facilitating achievement anxiety more than those who do not attend KPSS courses.

Table 4 shows the analysis results of whether or not the prospective teachers' achievement anxiety differs from their department of graduation. It was determined that both debilitating and facilitating achievement anxiety scores of prospective teachers did not significantly differ from their department of graduation $(\mathrm{P}>, 050)$.

Whether or not the arithmetic means of prospective teachers' debilitating and facilitating achievement anxiety scores significantly differ from the number of taking exams, one-way variance analysis (ANOVA) was conducted. Table 5 shows that there were statistically significant differences between both the arithmetic means of debilitating achievement anxiety scores $(\mathrm{F}=4,494 ; \mathrm{p}<.050)$ and facilitating achievement anxiety scores $(\mathrm{F}=7,501 ; \mathrm{p}<.050)$.

Scheffe multiple comparison method was used for determining the differences occurred among which groups. It was discovered that the significant difference for debilitating anxiety scores were stated in favor of the participants who took the KPSS for first time against the ones who took the exam for second time. In other words, the participants who took the KPSS for the first time felt debilitating achievement anxiety more than the ones who took the exam for the second time. A similar finding was found for facilitating anxiety scores. To this respect, it was found that facilitating anxiety scores of participants who took the KPSS for first time were significantly higher than the ones who took the exam for the second time.

Table 4. T.A. Kruskal Wallis-H Test for department of graduation and achievement anxiety

\begin{tabular}{|c|c|c|c|c|c|c|}
\hline Achievement Anxiety & Variables & $\mathrm{n}$ & Mean Rank & $x^{2}$ & $\mathrm{df}$ & $\mathrm{p}$ \\
\hline \multirow{5}{*}{ Debilitating Anxiety } & Technical Teachers & 170 & 155,30 & \multirow{5}{*}{, 874} & \multirow{5}{*}{3} & \multirow{5}{*}{, 832} \\
\hline & Secondary Education Branches & 54 & 151,25 & & & \\
\hline & Preschool Education Branches & 63 & 165,49 & & & \\
\hline & Foreign Language Branches & 25 & 153,36 & & & \\
\hline & Total & 312 & & & & \\
\hline \multirow{5}{*}{ Facilitating Anxiety } & Technical Teachers & 170 & 156,52 & \multirow{5}{*}{5,128} & \multirow{5}{*}{3} & \multirow{5}{*}{, 163 } \\
\hline & Secondary Education Branches & 54 & 134,94 & & & \\
\hline & Preschool Education Branches & 63 & 167,50 & & & \\
\hline & Foreign Language Branches & 25 & 175,22 & & & \\
\hline & Total & 312 & & & & \\
\hline
\end{tabular}

Table 5. One Way ANOVA for number of taking exams and achievement anxiety

\begin{tabular}{|c|c|c|c|c|c|c|c|c|c|}
\hline $\begin{array}{l}\text { Achievement } \\
\text { Anxiety }\end{array}$ & $\begin{array}{c}\text { Number of Taking } \\
\text { Exams }\end{array}$ & $N$ & $\overline{\mathrm{X}}$ & s.d & $\begin{array}{l}\text { Source of } \\
\text { Variance }\end{array}$ & $\begin{array}{l}\text { Sum of } \\
\text { Square }\end{array}$ & $\mathrm{df}$ & Mean of Square & $F$ \\
\hline \multirow{4}{*}{$\begin{array}{l}\text { Debilitating } \\
\text { Anxiety }\end{array}$} & First Time & 189 & 30,43 & 4,85 & Within G. & 197,928 & 2 & 98,964 & \multirow{4}{*}{$4,494 * *$} \\
\hline & Second Time & 75 & 28,52 & 3,81 & Between G. & 6805,187 & 309 & 22,023 & \\
\hline & Third or More & 48 & 29,95 & 5,23 & Total & 7003,115 & 311 & & \\
\hline & Total & 312 & 29,90 & 4,74 & & & & & \\
\hline \multirow{4}{*}{ Facilitating Anxiety } & First Time & 189 & 29,84 & 4,13 & Within G. & 339,284 & 2 & 169,642 & \multirow{4}{*}{$7,501 * *$} \\
\hline & Second Time & 75 & 27,34 & 5,29 & Between G. & 6988,204 & 309 & 22,616 & \\
\hline & Third or More & 48 & 28,83 & 6,01 & Total & 7327,487 & 311 & & \\
\hline & Total & 312 & 29,08 & 4,85 & & & & & \\
\hline
\end{tabular}

$* * * \mathrm{p}<.001 ; \quad * * \mathrm{p}<.010 ; \quad * \mathrm{p}<.050$


Table 6. One Way ANOVA for daily study hours and achievement anxiety

\begin{tabular}{|c|c|c|c|c|c|c|c|c|c|}
\hline $\begin{array}{c}\text { Achievement } \\
\text { Anxiety }\end{array}$ & Daily Study Hours & $N$ & $\overline{\mathrm{X}}$ & s.d & $\begin{array}{l}\text { Source of } \\
\text { Variance }\end{array}$ & $\begin{array}{l}\text { Sum of } \\
\text { Square }\end{array}$ & df & Mean of Square & $F$ \\
\hline \multirow{4}{*}{$\begin{array}{l}\text { Debilitating } \\
\text { Anxiety }\end{array}$} & $0-2$ hours & 194 & 30,50 & 4,74 & Within G. & 260,956 & 2 & 130,478 & \multirow{4}{*}{$5,980 * *$} \\
\hline & 2-4 hours & 77 & 29,51 & 4,60 & Between G. & 6742,160 & 309 & 21,819 & \\
\hline & More than 4 hours & 41 & 27,80 & 4,43 & Total & 7003,115 & 311 & & \\
\hline & Total & 312 & 29,90 & 4,74 & & & & & \\
\hline \multirow{4}{*}{ Facilitating Anxiety } & $0-2$ hours & 194 & 29,23 & 4,75 & Within G. & 17,706 & 2 & 8,853 & \multirow{4}{*}{, 374} \\
\hline & 2-4 hours & 77 & 28,67 & 4,72 & Between G. & 7309,781 & 309 & 23,656 & \\
\hline & More than 4 hours & 41 & 29,17 & 5,58 & Total & 7327,487 & 311 & & \\
\hline & Total & 312 & 29,08 & 4,85 & & & & & \\
\hline
\end{tabular}

$* * * \mathrm{p}<.001 ; \quad * * \mathrm{p}<.010 ; \quad * \mathrm{p}<.050$

Whether the arithmetic means of prospective teachers' debilitating and facilitating achievement anxiety scores significantly differ from daily study hours or not, one-way variance analysis (ANOVA) was conducted. According to the results, Table 6 shows that there was a statistically significant difference between arithmetic means of debilitating achievement anxiety scores $(F=5,980 ; p<.050)$. However, there was no statistically significant difference between arithmetic means of facilitating anxiety scores of prospective teachers $(\mathrm{F}=, 374 ; \mathrm{p}>, 050)$.

Scheffe multiple comparison method was used for determining the significant differences found between debilitating anxiety scores of prospective teachers occurred among which groups. According to the results, it was determined that the significant difference for debilitating anxiety scores were stated in favor of the participants who studied between 0-2 hours daily against the ones who studied more than 4 hours daily. That is to say, the participants who studied 0-2 hours daily felt debilitating achievement anxiety more than the ones who studied daily more than 4 hours.

\section{Discussion}

In this chapter, the findings obtained from the results of statistical analysis according to the aim of the study evaluated in the scope of literature and other related studies.

According to the obtained findings, there were positive significant relationships between debilitating anxiety scores of prospective teachers and attitudes to KPSS scale avoidance and the inconsistency of exam content sub-dimensions scores; however, there were negative significant relationships between debilitating anxiety scores of prospective teachers and academic contribution, the idea of justice and convergence sub-dimension scores. There was no significant relationship between debilitating anxiety score and emotional stress sub-dimension score. There were negative significant relationships between facilitating anxiety scores of prospective teachers and attitudes to KPSS scale avoidance, emotional stress and the inconsistency of exam content sub-dimensions scores; whereas, there were positive significant relationships between facilitating anxiety scores of prospective teachers and academic contribution and the idea of justice sub-dimension scores; and there was no significant relationship between convergence sub-dimension scores. It is known that attitudes directly affect a person's behaviors, feelings and thoughts to that fact [19]. Thus, it can be asserted that the findings are expected ones which show the relations between positive attitudes towards KPSS of prospective teachers and motivating effect of achievement anxiety, and relations between negative attitudes and demotivating effect of achievement anxiety.

At the result of conducted analysis to determine whether the debilitating and facilitating achievement anxieties of participants differ from their genders or not, both debilitating and facilitating achievement anxieties of participants did not significantly differ from their genders. Examining the similar studies, different findings were seen. While the study of Yücel-Koç [21] conducted on test anxiety in general with prospective teachers presented that male prospective teachers had higher text anxiety than female teachers, Şenöz [23] and Yalçınkaya [24] stated in their studies conducted separately with adolescents that female students had higher test/exam anxiety. According to the findings of their researches, for elementary school prospective teachers, Alşahan [25]; for the students of faculty of education, Doğan and Çoban [26]; and for adolescents, Biçkur [27] pointed out that test anxiety did not differ from gender. Different findings related to gender in literature show that gender is not an effective variable alone itself for achievement-test anxiety; gender has an effect with other variables.

As a result of conducted analysis to determine whether the debilitating and facilitating achievement anxieties of prospective teachers differ from their status of attending KPSS courses or not, both debilitating and facilitating achievement anxiety scores of prospective teachers who were attending KPSS courses were significantly higher than those who were not attending KPSS courses. The obtained finding was grounded by the hypothesis that prospective teachers who have been attending KPSS courses take the exam more seriously and consider it as important in their lives. In this context, it can be asserted that the findings were expected.

The result of conducted analysis to determine whether the 
achievement anxieties of prospective teachers differ from departments of graduation or not, both debilitating and facilitating achievement anxiety scores of participants did not significantly differ from their departments of graduation variable. Rather than their departments of graduation, their future anxieties in common have an important role to determine these findings.

As a result of statistical analysis to determine whether the debilitating and facilitating achievement anxiety scores of prospective teachers significantly differ from the number of taking exams variable or not, it was seen that both debilitating and facilitating achievement anxiety scores' arithmetic means were significantly different. The analysis carried out to determine the differences occurred among which groups showed that debilitating anxiety scores were found out in favor of the prospective teachers who took the KPSS for the first time against the ones who took the exam for second time. A similar finding was found for facilitating anxiety scores. It was found that facilitating anxiety scores of participants who took the KPSS for first time were significantly higher than the ones who took the exam for the second time. There is no research carried out on this topic with prospective teachers. However, Yağcı [28] stated that the number of taking exams did not significantly differ from test/exam anxiety among students who were preparing for the university entrance exam. Actually considering the developmental period of study group helps us to understand better the results of this study. According to Erikson (2014), this stage is defined as "intimacy vs. isolation" and one of the most important developmental duties of this stage is to start working and to be on the productive position. Shaped by the society as well, this duty puts pressure on the individual and thus, anxiety occurs. The anxiety increases with being late to fulfil this duty.

Lastly, the result of analysis to determine whether the debilitating and facilitating achievement anxiety scores of prospective teachers significantly differ from daily study hours variable or not, it was seen that there was a statistically significant difference between arithmetic means of their debilitating anxiety scores. However, there was no statistically significant difference between arithmetic means of facilitating achievement anxiety scores of prospective teachers. Scheffe multiple comparison method was used for determining the significant differences found between debilitating anxiety scores of prospective teachers occurred among which groups. According to the results, it was determined that the significant difference for debilitating anxiety scores were stated in favor of the prospective teachers who studied daily $0-2$ hours against the ones who studied daily more than 4 hours. That is to say, the participants who studied 0-2 hours daily felt debilitating achievement anxiety more than the ones who studied daily more than 4 hours. Examining the KPSS content, prospective teachers are subjected to many exams such as general culture (minimum 3 lessons), general knowledge and skills (minimum 2 lessons), educational sciences (minimum 8 lessons) and academic information of studied department (almost for all bachelor's degree program). Since there are many subjects, it is supposed to study a lot on daily basis. If the students do not allocate enough time for studying, he/she will not be fully prepared for the exam and that situation brings anxiety as expected.

In the light of the findings, these are recommended:

To reduce the achievement anxiety of prospective teachers, psychoeducation programs may be prepared for making them realize their negative attitudes towards KPSS and changing them into a positive way;

Firstly universities and related institutions should revise the content of actual examination method for staffing teachers in our country;

By highlighting the problems faced on the discussion chapter of this study, conducting similar studies that will investigate the subject deeply with different prospective teachers' samples is important.

\section{REFERENCES}

[1] Civil, Ş. (2008). A research into the test anxiety level of the senior students (8th grades) of state and private primary scholls in Kadiköy district of İstanbul anatolian side caused by the OKS (secondary school student selection and placement exam). Unpublished Master Thesis Yeditepe University, Istanbul, Turkey.

[2] Gençtan, E. (1990). Psychoanalysis and beyond. 4. Edition, İstanbul: Remzi.

[3] Öner, N., Le Compte A. (1998). Handbook of trait/state anxiety inventory. (Second edition), İstanbul: Bogazici University.

[4] Cüceloğlu, D. (1991). Human and theirs behaviors. Istanbul: Remzi.

[5] Yavuz, Ç., Akagündüz, N. (2004). Being child. İstanbul: Ümraniye Guidance and Exploration Center.

[6] Sarason, I. G. (Ed). (1980), Test anxiety: Theory research and applications, Hillsdale,Ns. Erlbaum.

[7] Spielberger. C., Vagg, R. (1995). Test anxiety: theory, assessment, and treatment. the series in clinical and community psychology. Taylor and Francis.

[8] Semerci, B. (2007). Test anxiety and coping. İstanbul: Merkez.

[9] Wittmajer, B. C. (1972). Test anxiety and study habits. Journal of Educational Research, (65): 352-354.

[10] Coleman, J. C., Broen, W. E. (1972). Abnormal psychology and modern life, Scott, Foresman and Company, 4. Edition, U.S.A.

[11] Kılıç, B. G., Koçkar, A. İ., Şener, Ş. (2002). Test anxiety and academic achievement in preschool students. Journal of Child and Youth Mental health, 9(2): 100-103.

[12] Yıldırım, İ., Ergene, T. (2003). Social support, submissive acts, and test anxiety as predictors of academic achievement among high school students. Hacettepe University Education Faculty Journal, 25: 224-234. 
[13] Kapıkıran, N. (1999). The Studying of achievement responsibility and achievement anxiety with psychopathological variables of lise students. Unpublished Doctoral Thesis Dokuz Eylül University, Izmir, Turkey.

[14] Elcin Boyacioglu, N., Kücük L. (2011). How do irrational beliefs affect test anxiety during adolescence? Journal of Psychiatric Nursing, 2(1): 40-45.

[15] Bildik, T. (2007). Test anxiety. İzmir: İlya.

[16] Öner, N. (1990). Handbook of inventory of test anxiety. Istanbul: YÖRET.

[17] Yurdabakan, İ. (2009). The affect of group guidance to test anxiety in secondary education 8th class (Edt: S. Erkan ve A. Kaya) Group counselling and guidance programmes as tested experimentally. Ankara: Pegem.

[18] Kağıtçbaşı, Ç., (1999). Again human and humans. İstanbul: Evrim.

[19] Tavşancıl, E. (2005). Measurement of attitudes and data analysis with SPSS. Ankara: Nobel.

[20] Deveci, H. (2003), The effect of problem based learning to attitudes, success and retention in social studies. Unpublished Master Thesis Anadolu University, Eskisehir, Turkey.

[21] Ümmet, D., Otrar, M. (2015). A study of attitudes scale for public staff examination, Gümüshane University Electronic Journal of the Institute of Social Sciences, 6(13): 1-14.

[22] Yücel Koç, İ. (2013). Research on correlation between learning styles and exam anxiety of preservice teachers preparing for kpss test. Unpublished Master Thesis, Yeditepe University, Istanbul, Turkey.

[23] Şenöz, G. (2015). Rate of anxiety disorder evaluation of the incidence of the 8th grade students who was diagnosed as obsessive compulsive disorder. Unpublished Master Thesis, Beykent University, Istanbul, Turkey.

[24] Yalçınkaya, N. (2011). An Examination of relation between primary 8th grade students' attitudes towards Turkish courses and their level of test anxiety. Unpublished Master Thesis, Nigde University, Nigde, Turkey.

[25] Alşahan, Ö. L. (2010). Research on learning technics of primary school teacher nominees. Unpublished Master Thesis Frrat University, Elezig, Turkey.

[26] Doğan, T. Çoban, A. E. (2009). The investigation of the relations between students' attitude toward teaching profession and anxiety level in faculty of education. Education and Science, 34(153): 157-168.

[27] Biçkur, B. (2015). The analysing between exam anxiety and self-esteem of student who take university exam and attitudes of their parents. Unpublished Master Thesis Usküdar University, Istanbul, Turkey.

[28] Yagc1, M. V. (2010). Relationship between the social support the students who prepare for the university entrance exam have got and text anxiety. Unpublished Master Thesis, Gazi University, Ankara, Turkey.

[29] Erikson, E. H. (2014). Eight stages of man (Translate: Gonca Akkaya) İstanbul: Okyanus.

\footnotetext{
This study was presented as verbal notice at International Conference on New Horizons in Education-2016 in Vienna with the support of Marmara University Scientific Research Project Commission (BAPKO Project No: EGT-D-250416-0207.
} 